\title{
The role of iron and black carbon in aerosol light absorption
}

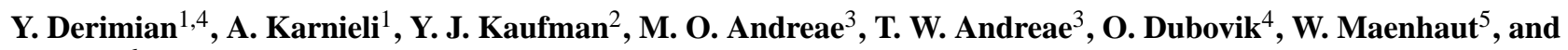 \\ I. Koren ${ }^{6}$ \\ ${ }^{1}$ Major part of this study was done while at: Jacob Blaustein Institute for Desert Research, Ben Gurion University of the \\ Negev, Israel \\ ${ }^{2}$ NASA Goddard Space Flight Center, NASA Goddard SFC, USA \\ ${ }^{3}$ Max Planck Institute for Chemistry, Mainz, Germany \\ ${ }^{4}$ Laboratoire de Optique Atmosphérique, Université de Lille 1/CNRS, Villeneuve d'Ascq, France \\ ${ }^{5}$ Ghent University (UGent), Department of Analytical Chemistry, Institute for Nuclear Sciences, Gent, Belgium \\ ${ }^{6}$ Department of Environmental Sciences, Weizmann Institute, Rehovot 76100, Israel
}

Received: 8 May 2007 - Published in Atmos. Chem. Phys. Discuss.: 13 June 2007

Revised: 26 February 2008 - Accepted: 3 June 2008 - Published: 10 July 2008

\begin{abstract}
Iron is a major component of atmospheric aerosols, influencing the light absorption ability of mineral dust, and an important micronutrient that affects oceanic biogeochemistry. The regional distribution of the iron concentration in dust is important for climate studies; however, this is difficult to obtain since it requires in-situ aerosol sampling or simulation of complex natural processes. Simultaneous studies of aerosol chemical composition and radiometric measurements of aerosol optical properties, which were performed in the Negev desert of Israel continuously for about eight years, suggest a potential for deriving a relationship between chemical composition and light absorption properties, in particular the spectral single-scattering albedo.

The two main data sets of the present study were obtained by a sun/sky radiometer and a stacked filter unit sampler that collects particles in coarse and fine size fractions. Analysis of chemical and optical data showed the presence of mixed dust and pollution aerosol in the study area, although their sources appear to be different. Spectral SSA showed an evident response to increased concentrations of iron, black carbon equivalent matter, and their mixing state. A relationship that relates the spectral SSA, the percentage of iron in total particulate mass, and the pollution components was derived. Results calculated, using this relationship, were compared with measurements from dust episodes in several locations around the globe. The comparison showed reasonable agree-
\end{abstract}

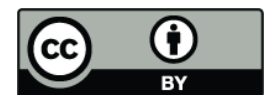

Correspondence to: Y. Derimian (derimian@loa.univ-lille1.fr) ment between the calculated and the observed iron concentrations, and supported the validity of the suggested approach for the estimation of iron concentrations in mineral dust.

\section{Introduction}

The presence of iron $(\mathrm{Fe})$ in aeolian dust is of wide interest in climate studies due to its biogeochemical and radiative impacts (Jickells et al., 2005; Mahowald et al., 2005). Iron oxides (primarily hematite and goethite) are major components that affect the ability of aeolian dust to absorb sunlight at short wavelengths (the blue spectral region). Variable concentrations of iron oxide alter the dust's radiative properties (make dust darker or brighter) and thus may influence climate (Sokolik and Toon, 1999). Bio-available iron is an important micronutrient that affects oceanic biogeochemistry (Fan et al., 2006). Following dust deposition in oceanic regions (Fung et al., 2000; Colarco et al., 2003; Gao et al., 2003; Johnson et al., 2003; Kaufman et al., 2005b), iron fertilization supports phytoplankton growth and the cycles of other oceanic nutrients and bacteria (Martin and Gordon, 1988; Behrenfeld et al., 1996; Coale et al., 1996; Capone et al., 1997; Falkowski, 1997; Boyd et al., 2000; Jickells et al., 2005; Mongin et al., 2006). Subsequently, changes in the photosynthetic activity of phytoplankton alter the cycle of atmospheric $\mathrm{CO}_{2}$ and of global carbon (Broecker and Henderson, 1998; Watson et al., 2000). The variability of iron concentrations supplied by aeolian dust may also be of importance for oceanic biota in various ocean regions where

Published by Copernicus Publications on behalf of the European Geosciences Union. 
dust deposition is significant (Gao et al., 2001; Wiggert et al., 2006).

Transported aeolian dust can be contaminated by anthropogenic aerosols and thus contain products of industrial and motor vehicle combustion emissions, or products of biomass burning. Such aerosols contain light-absorbing carbon that is a strong absorber and therefore contributes to global warming (Jacobson, 2004; Chung and Seinfeld, 2005). Dubovik et al. (2002a) showed that the spectral absorption of pollution aerosols is distinctive from that of mineral dust. The spectral absorption properties of light-absorbing carbon depend on the origin of the material and combustion conditions (Andreae and Gelencser, 2006; Schkolnik et al., 2007). Strongly absorbing black soot particles are commonly called black carbon (BC) and are characterized by a decrease of absorption towards long wavelengths proportional to $1 / \lambda$ (Kirchstetter et al., 2004). In addition, the combustion of organic matter, such as biomass, or smoldering combustion may produce particles containing light-absorbing organic compounds. These particles have relatively strong absorption in the UV, and are denoted as brown carbon; they are suggested to be of higher relevance for regions outside of those that are highly industrialized and for cases where light absorption is not dominated by pure soot (Andreae and Gelencser, 2006). Here we will use the quantity "black carbon" (BC), operationally defined as the amount of strongly light-absorbing carbon with the approximate optical properties of soot carbon, which would give the same signal in our optical instrument as the sample. While the term "BC" has become common usage in various contexts, the operationally defined $\mathrm{BC}$ implies an optically equivalent meaning (Hansen et al., 1984; Bond and Bergstrom, 2006). In the present study we would like to emphasize the optical equivalency of the measured values.

Several approaches can be used for evaluation of iron or BC concentrations in particulate matter, e.g., in-situ sampling of atmospheric aerosol particles with further laboratory analysis. However, in-situ sampling requires considerable effort, and can even be impossible for providing results of wide spatial and temporal coverage. Another possibility is to employ chemistry transport model simulations. Although models are able to represent anthropogenic emissions, the adequate estimation of $\mathrm{BC}$ concentrations remains challenging (Bond et al., 2004; Streets et al., 2004). The prediction of natural components, such as iron concentrations, depends on wind speeds and local mineralogy, and thus may carry even more uncertainty (Kaufman et al., 2005a). An additional approach is modeling of aerosol optical properties (Sokolik and Toon, 1999), which can be employed for inversion of measurable aerosol optical characteristics and deriving concentrations of chemical elements. Modeling of complex refractive index, aerosol scattering and absorption coefficients for various combinations of minerals was recently improved by incorporation of the results of specifically designed measurements (Lafon et al., 2006). In their study Lafon et al. (2006) composed dust mixtures from some key minerals, including hematite and goethite, typically found in soils and aerosol samples. Laboratory-obtained information on the fraction of minerals in different size modes was included in the modeling of aerosol optical properties. Schuster et al. (2005) demonstrated an approach of inversion of AERONET retrievals into chemical elements concentrations (namely BC) and specific absorption, using an effective medium approximation. This approximation enables effective optical constants calculation of internally mixed chemical elements in various volume fractions. An advantage of the approach suggested by Schuster et al. (2005) lies in tying the effective medium approximation to real optical measurements of ambient aerosols. Alfaro et al. (2004) employed aethalometer and nephelometer laboratory measurements to experimentally derive the spectral mass absorption efficiency and SSA of dust aerosols. They also estimated the relative contributions for the mixture of iron oxides and $\mathrm{BC}$ on dust absorption. They found agreement between the calculated SSA and the one derived from the inversion of sun/sky radiometer measurements (Dubovik and King, 2000). Other studies showed the possibility of deconvoluting dust and BC spectral absorption and scattering properties, and thereby inferring iron and BC concentrations. For instance, Fialho et al. (2005) differentiated the absorption spectral dependence of dust and $\mathrm{BC}$ measured by an aethalometer. In a subsequent study, Fialho et al. (2006) calibrated these measurements with Fe on the filters, and derived empirical calibration constants for the determination of the iron concentration from the aethalometer observations. Koven and Fung (2006) employed a similar concept of absorption spectral dependence for the characterization of dust composition; however, they studied sun/sky radiometer measurements through the whole atmospheric column (AERONET) and incorporated the mineralogical effects by using different modeled relative fractions of hematite, silicate and BC.

The approach used in the present paper is similar to that of Koven and Fung (2006) and Schuster et al. (2005) in referring to aerosol scattering and absorption spectral properties derived from a sun/sky radiometer. However, we do not employ the effective medium approximation to connect the optical measurements to the aerosol chemical composition, but use the chemical element concentrations measured on filter samples of atmospheric aerosols. Specifically, we take advantage of a large data set of co-located, simultaneous longterm AERONET observations and aerosol sampling results. We use this data for deriving coefficients which relate spectral SSA and concentrations of $\mathrm{Fe}$ and $\mathrm{BC}$ in a developed equation. This approach avoids usage of bulk or modeled optical properties of a material, or absorption properties measured on aerosol samples after they have been removed from atmosphere. Instead, we utilize aerosol optical characteristics that correctly reflect the actual measured radiation field. We also do not reconstruct aerosol mineralogy or use soil characteristics, but refer to actual $\mathrm{Fe}$ and $\mathrm{BC}$ concentrations 
in real atmospheric aerosols.

The general motivation for this study was to assess iron concentrations in atmospheric dust by aerosol spectral absorption. The iron concentration in total dust mass can be useful for estimating the amounts of iron deposited to the ocean. We have analyzed the differential aerosol spectral absorption from the blue to the NIR (near infrared) spectral region, which should be proportional to the associated concentrations of iron and BC. In this study, we consider concentrations of total iron, and assume that the optically relevant iron oxides represent a fixed part of the total iron in airborne mineral dust. This iron oxide to total iron ratio may be unique for a given location with its specific sources, but at the end of Sect. 4.6 we discuss the reliability and restrictions of this assumption. The aerosol spectral absorption was obtained by inversion of sun/sky radiometer measurements (AERONET product). The aerosol chemical composition was obtained from aerosol sampling at ground level. Specific objectives were: (1) to correlate data sets for events where ground level aerosol chemistry was found to be representative for the total column optical measurement; (2) to estimate the contamination of atmospheric dust by $\mathrm{BC}$ and its role in aerosol spectral absorption; and (3) to derive a relationship between iron concentrations and differential aerosol spectral absorption.

\section{Site location}

Measurements were conducted at the Sede Boker (in some sources referred to as Sde Boker) Campus of the Ben-Gurion University of the Negev $\left(30^{\circ} 51^{\prime} \mathrm{N}, 34^{\circ} 47^{\prime} \mathrm{E}, 470 \mathrm{~m}\right.$ a.m.s.l.), Israel. The site is located in the eastern Mediterranean region, characterized by relatively high levels of tropospheric aerosol burden due to the influence of anthropogenic aerosols that originate mainly from Europe, and mineral dust from the North African, Sinai, and Saudi Arabian deserts (Ichoku et al., 1999; Formenti et al., 2001; Andreae et al., 2002; Gerasopoulos et al., 2003; Israelevich et al., 2003; Kubilay et al., 2003). Specifically, Sede Boker is situated in the northern part of the Negev Desert, relatively far from highly populated and industrial areas. The climate is dry, with a mean annual precipitation of 100-200 $\mathrm{mm}$ and $20-40$ rainy days throughout the year. The average relative humidity at 14:00 local time for July is $30-35 \%$ and for January, $40-50 \%$ (Stern et al., 1986).

\section{Data sets and instrumentation}

The main data sets were obtained from a CIMEL sun/sky radiometer, part of the global Aerosol Robotic Network (AERONET), and a "Gent" PM10 stacked filter unit (SFU) sampler. Additional data were obtained from a singlewavelength integrating nephelometer and a scanning electron microscope (SEM) equipped with an energy dispersive spectrometer (EDS).

\subsection{Sun/sky radiometer}

The AERONET program is an automatic robotic sun and sky scanning measurement initiative (Holben et al., 1998). A CIMEL spectral radiometer performs direct sun measurements every $15 \mathrm{~min}$, with a $1.2^{\circ}$ field of view at 340,380 , $440,500,675,870,940$, and $1020 \mathrm{~nm}$ nominal wavelengths. The spectral aerosol optical thickness (AOT or $\tau_{\text {ext }}$ ) was retrieved at seven of these wavelengths from the direct sun measurements; the $940 \mathrm{~nm}$ channel was used to retrieve water vapor content. The angular distribution of sky radiance was also measured at 440,670, 870, and $1020 \mathrm{~nm}$. The measured spectral sun and sky radiances were used to retrieve aerosol optical parameters at four wavelengths by the AERONET inversion code (Dubovik and King, 2000).

In this paper we utilize data from Version 2 (V2) inversion products. V2 inversion partitions aerosol particles into spherical and non-spherical components, which are modeled by an ensemble of polydisperse, homogeneous spheres and a mixture of polydisperse, randomly-oriented homogeneous spheroids (Mishchenko et al., 1997) with a fixed spheroid aspect ratio distribution (Dubovik et al., 2006). The retrievals utilized also contain redefined surface reflectance properties, which are obtained by the inclusion of combined satellite data, and which account for possible improvements in retrieved aerosol properties and single-scattering albedo in particular (Sinyuk et al., 2007). In addition, all restrictions recommended in Dubovik et al. (2002a) for reliability of the inversion product were applied. More details on the development of the retrieval algorithm, modifications and accuracy assessments can be found in Dubovik and King (2000), Smirnov et al. (2000), Dubovik et al. (2000; 2002a; 2002b), and Sinuyk et al. (2007).

\section{2 "Gent" PM10 stacked filter unit sampler}

The "Gent" PM10 stacked filter unit (SFU) sampler collects particles on Nuclepore polycarbonate filters in a coarse (2$10 \mu \mathrm{m}$ aerodynamic diameter (AD)) and a fine $(<2 \mu \mathrm{m} \mathrm{AD})$ size fraction. The SFU sampler is operated continuously on a two-two-three-day scheme. The instrument was located at about $8 \mathrm{~m}$ above the ground and operated at an air flow rate of $\sim 16 \mathrm{~L} \mathrm{~min}^{-1}$. To avoid the problem of filter clogging and consequently non-representative measurements in the twotwo-three-day scheme, the sampling was always conducted with a timer set at $50 \%$ for the two-day sample and at $33 \%$ for the three-day sample, thus the SFU effectively sampled only 50 or $33 \%$ of the time evenly distributed over two or three days, respectively. This generally results in little clogging or effects from a decrease in flow rate during the sampling, except possibly during episodes of extremely high aerosol concentrations. The volume of the sampled air is obtained from a volume meter, which is accurate within $5 \%$ and is not affected by the concentration of the aerosol in the air or by the filter loading. The SFU samples were analyzed for 
particulate mass (PM), in $\mu \mathrm{g} \mathrm{m}^{-3}$, for over 40 elements including $\mathrm{Fe}$, in $\mathrm{ng} \mathrm{m}^{-3}$, and black carbon (BC), also in $\mu \mathrm{g}$ $\mathrm{m}^{-3}$. The PM was measured using gravimetry at $20^{\circ} \mathrm{C}$ and $50 \%$ relative humidity. The uncertainty associated with the weighing is usually less than $3 \%$ for the coarse PM and less than 5\% for the fine PM. More than 40 elements were measured using a combination of instrumental neutron activation analysis (INAA) and particle-induced X-ray emission analysis (PIXE). BC, that is black carbon corresponding to a measured light extinction at fixed mass absorption efficiency, was measured by a light reflectance technique. The measurements were performed with a commercial smoke stain reflectometer (Diffusion Systems Ltd, London, UK, model 43) that uses white light. Instead of assuming a mass absorption efficiency (MAE, in $\mathrm{m}^{2} \mathrm{~g}^{-1}$ ), the instrument was calibrated with secondary standards for BC determination. These secondary standards were produced by depositing soot from acetylene burning on filters. The MAE that corresponds to the calibration factor obtained by reflectance measurements of the secondary standards is estimated as being around $5 \mathrm{~m}^{2} \mathrm{~g}^{-1}$. More details about the SFU samples and the chemical analysis, including studies conducted at the Sede Boker site, have been discussed by Maenhaut et al. (1996a; 1996b; 1997) and Andreae et al. (2002). In addition, in Sect. 4.2 we will discuss the possible effects of extra light absorption by other species and their contribution to the $\mathrm{BC}$ signal.

\subsection{Nephelometer}

The Integrating Nephelometer (M903, Radiance Research, Seattle, WA, USA) measures the light scattering extinction coefficient $\left(\sigma_{\text {scat }}\right)$ with a 2 -min resolution at a wavelength of $545 \mathrm{~nm}$, with a scattering angular range of $7-170^{\circ}$. The instrument is operated indoors and air is supplied through a plastic tubing of up to $3 \mathrm{~m}$ length and of $2.2 \mathrm{~cm}$ internal diameter. The inlet of the tubing is located outdoors at about $10 \mathrm{~m}$ above ground level and faces downwards. Pressure, temperature, and relative humidity (RH) in the scattering volume of the instrument are also monitored and recorded. In order to eliminate a non-linear increase in $\sigma_{\text {scat }}$ due to high humidity, the data with $\mathrm{RH}>80 \%$ were removed (Andreae et al., 2002).

\subsection{Scanning electron microscope}

The high-resolution field emission scanning electron microscope (SEM) LOE 1530, equipped with an energy dispersive X-ray (EDX) spectrometer, at the Max Planck Institute for Chemistry, Mainz, was used for visualization and qualitative analysis of individual aerosol particles collected on the $\mathrm{Nu}$ clepore polycarbonate filters of the SFU samples. The working conditions for the images presented here were set at an accelerating voltage of 5 or $15 \mathrm{kV}$ and magnification varied from about $70000 \mathrm{X}$ to $400000 \mathrm{X}$. This enabled the observa- tion of particles and their structures in sizes from a few tens to hundreds of nanometers.

\section{Data analysis and discussion}

This section presents an analysis of aerosol absorption obtained from radiometric measurements (Sect. 4.1.), aerosol chemistry obtained from in-situ surface sampling (Sect. 4.2. and 4.3.), their integration (Sect. 4.4.), and development of a physical model for establishing the relationship between aerosol spectral absorption and chemistry (Sect. 4.5). The proposed relationship is examined with data for several locations (Sect. 4.6).

\subsection{Radiometric observations}

The single-scattering albedo (SSA or $\omega_{0}$ ) is the ratio of light scattering to total light extinction (scattering and absorption) and represents scattering effectiveness relative to total extinction. Therefore, SSA decreases when absorption increases. Mineral dust and aerosol particles originating from combustion processes have different wavelength dependencies for SSA (Dubovik et al., 2002a). This difference in aerosol spectral absorption is predominantly related to absorption by two components, iron oxide and black carbon. The SSA for mineral dust usually decreases towards short wavelengths due to the presence of iron oxide. The SSA for anthropogenic pollution aerosols that contain $\mathrm{BC}$ decreases towards long wavelengths (Dubovik et al., 2002a). Thus, the presence of iron oxide or BC in aerosols can be determined by examining the behavior of the spectral SSA.

The mean spectral single-scattering albedo obtained during about eight years of measurements at Sede Boker for periods with predominantly coarse ( $\AA$ ngström exponent $(a)<0.6)$ and increased contribution of fine $(\stackrel{a}{>}>1.0)$ aerosol, respectively, is presented in Fig. 1. The Ångström exponent represents the wavelength dependence of extinction and is calculated by

$\stackrel{\mathrm{a}}{=}=-\frac{\ln \left(\tau_{\mathrm{ext}}^{870} / \tau_{\mathrm{ext}}^{440}\right)}{\ln \left(\lambda^{870} / \lambda^{440}\right)}$.

In our study we employ the difference between SSA at $440 \mathrm{~nm}$ and $1020 \mathrm{~nm}$ (dSSA), which provides two advantages: first, it is expected that the difference will provide better accuracy than absolute values, since retrieval of spectral dependence is more reliable than that of an absolute value; and second, the spectral behavior of an SSA curve can be characterized by only one parameter, dSSA. Negative values of the difference SSA $(440 \mathrm{~nm})-\operatorname{SSA}(1020 \mathrm{~nm})$ will be related to stronger absorption by iron oxide at $440 \mathrm{~nm}$, while positive values are related to stronger absorption by $\mathrm{BC}$ containing particles at $1020 \mathrm{~nm}$. In this study we also utilized the Ångström exponent, which is a qualitative indicator of aerosol size. While fine or coarse mode fractions or an 


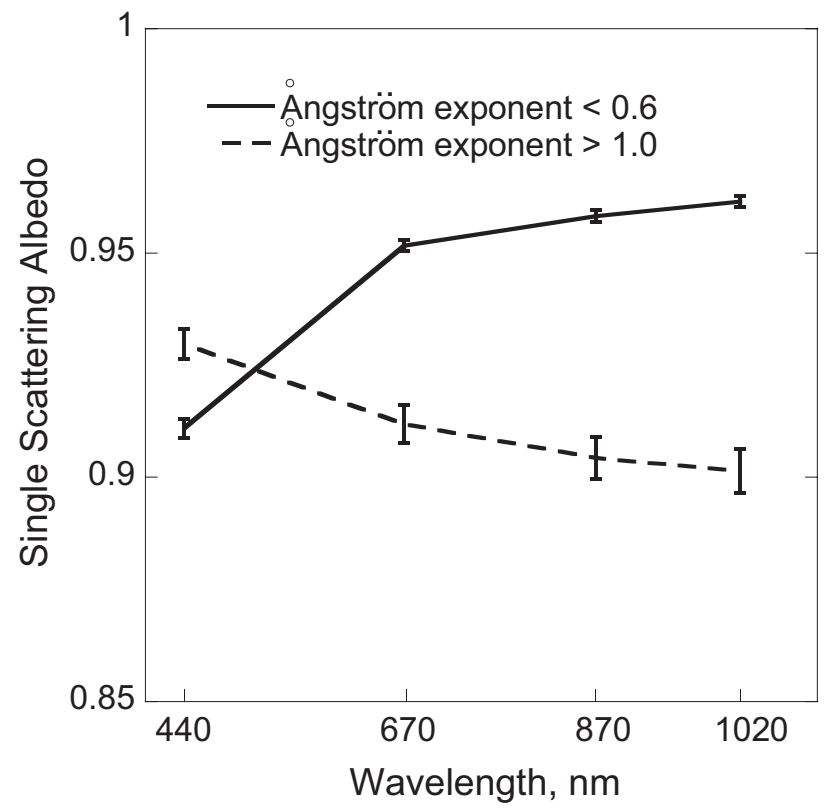

Fig. 1. Average spectral single-scattering albedo for periods with significant contributions of coarse (Ångström exponent $<0.6$ ) and fine (Ångström exponent $>1.0$ ) aerosol for about eight years of measurements at the Sede Boker site.

effective radius could better describe aerosol size (Eck et al., 1999; Schuster et al., 2006), we prefer to use the Ångström exponent as an easily measurable and always available parameter. It was also found in our test that the Ångström exponent was well correlated with the other aerosol size parameters.

Figure 2 shows all quality-assured observations of SSA(440)-SSA(1020) versus the Ångström exponent, which were made at the Sede Boker site from October 1995 to May 2006. The data presented in this figure are stratified into different ranges of SSA(1020) in order to indicate events with different levels of absorption at $1020 \mathrm{~nm}$. This figure reveals that, as the Ångström exponent $(870 \mathrm{~nm}-440 \mathrm{~nm})$ increases from about zero to about 1.5 (indicating a decreasing contribution of coarse dust particles and increasing fraction of fine pollution particles), spectral SSA gradually changes from stronger absorption at $440 \mathrm{~nm}$ to stronger absorption at $1020 \mathrm{~nm}$. It is noteworthy that absorption at $1020 \mathrm{~nm}$ is quite weak (marked by red diamonds and blue circles) for events dominated by coarse particles (Ångström exponent about zero). As the contribution from fine particles increases (Ångström exponent from 0.5 to 1.0 ), absorption is still strongest at $440 \mathrm{~nm}$, but absorption at $1020 \mathrm{~nm}$ becomes significant (part of observations marked by green squares). This spectral SSA behavior is related to mixtures of dust and pollution, with characteristic Ångström exponent values in the range from 0.5 to 1.0 . As the Angström exponent continues to increase, which means that the contribution of fine particles increases, absorption at $1020 \mathrm{~nm}$ becomes stronger

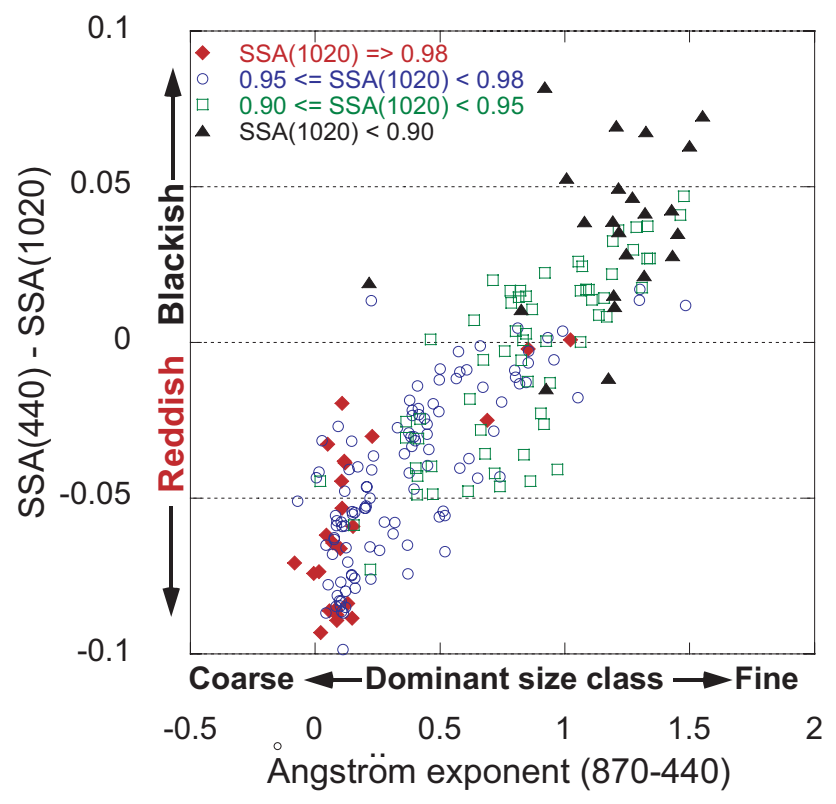

Fig. 2. Difference of $\operatorname{SSA}(440 \mathrm{~nm})-\operatorname{SSA}(1020 \mathrm{~nm})$ versus Ångström exponent. All observations were conducted at the Sede Boker site from October 1995 to May 2006. Different ranges of SSA $(1020 \mathrm{~nm})$ values are presented by different symbols and indicate events from weak to strong absorption at $1020 \mathrm{~nm}$.

than at $440 \mathrm{~nm}$ and $\mathrm{SSA}(1020 \mathrm{~nm})$ may reach values of 0.85 (black triangles). Consequently, Fig. 2 classifies spectral SSA for events having dust- or pollution-dominated contributions and different degrees of mixing.

\subsection{In-situ surface sampling}

Concentrations of $\mathrm{BC}$ and total $\mathrm{Fe}$ at ground level were measured simultaneously with the radiometric measurements. Figure 3 shows the percentage of $\mathrm{BC}$ versus the percentage of $\mathrm{Fe}$ in the PM10 total particulate mass (TPM). The BC or Fe percentages in the TPM (denoted hereafter as \% TPM) were calculated as the sum of $\mathrm{BC}$ or Fe concentrations $\left(\mu \mathrm{g} \mathrm{m}^{-3}\right)$ in the fine and coarse size fractions relative to the sum of the particulate mass concentrations $\left(\mu \mathrm{g} \mathrm{m}^{-3}\right)$ in the two size fractions. This figure shows a pattern of negative correlation between the percentages of $\mathrm{BC}$ and $\mathrm{Fe}$ in the TPM. This implies that, generally, sources of $\mathrm{BC}$ (pollution tracer) and $\mathrm{Fe}$ (mainly from dust) are different. Another conclusion, suggested by this plot, is that during most of the events both elements are present at measurable concentrations, i.e., that we generally have a mixture of dust and pollution aerosol at our sampling site.

It should be mentioned here that the $\mathrm{BC}$ concentration is measured by a light reflectance technique so that other species (e.g., $\mathrm{Fe}$ ) or even just an increase of total mass concentration $\left(\mu \mathrm{g} \mathrm{m}^{-3}\right)$ on the filter during a dust event may contribute to the BC signal by additional light absorption. To test for these potential interferences, we examine the possible 


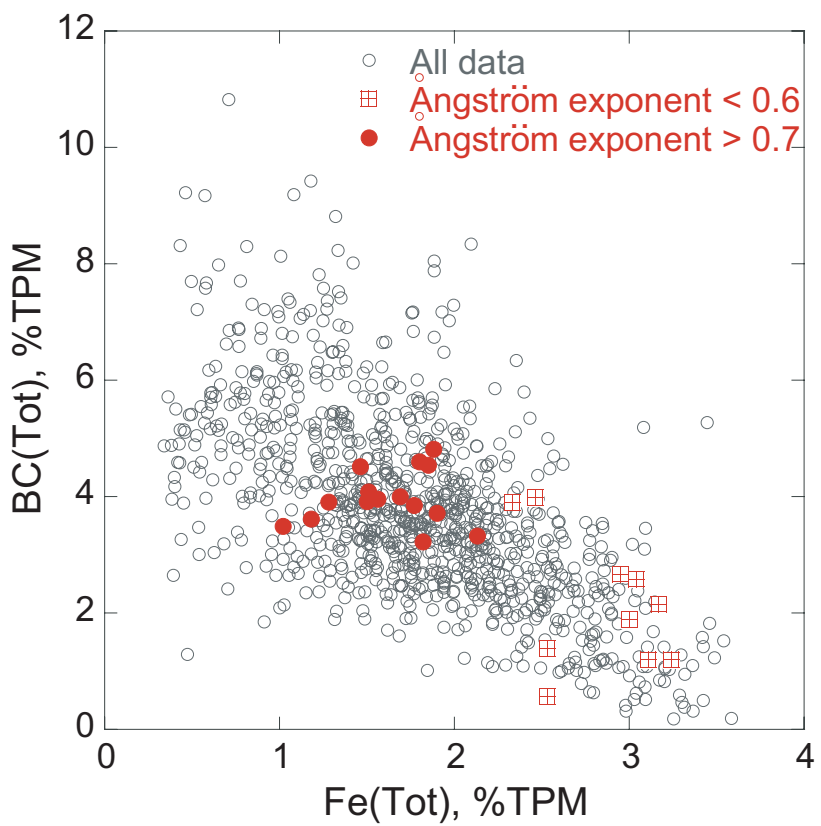

Fig. 3. $\mathrm{BC}$ percentage of the total particulate mass (BC, \% TPM) versus $\mathrm{Fe}$ percentage of the total particulate mass (Fe, \% TPM). Black open circles represent all available data, red solid circles (Ångström exponent <0.6) and open squares (Ångström exponent $>0.7)$ represent a subset of data matched to optical column measurements.

influence of $\mathrm{Fe}$ and high mass concentrations on the $\mathrm{BC}$ signal (Fig. 4). This figure shows BC, \%TPM in the fine fraction, versus Fe, \% TPM in the coarse fraction. Different ranges of total mass concentration are indicated by different symbols. Figure 4 reveals that (1) fine BC of pollution origin is not positively correlated with dust-related coarse Fe; (2) increase in mass concentration does not coincide with an increase of BC, \% TPM in fine fraction; and (3) increase in total mass concentration is clearly coincident with an increase in coarse Fe, \%TPM. Later, in Fig. 7, we will also show that the main part of $\mathrm{BC}$ is found in the fine and that of $\mathrm{Fe}$ in the coarse size fraction. Thus, an increase in Fe, \% TPM or total mass concentration does not cause a spurious increase in the measured BC, \% TPM.

\subsection{Individual particle analysis}

Four pairs of SFU sample filters (coarse and fine) from four dust storm events were analyzed by scanning electron microscope (SEM) in order to examine microphysical characteristics and possible mixing of the sampled aerosols. In this paper we present a few images from analyzed dust events on 2 April 2000 and 3 February 2001 in order to illustrate dust and pollution mixing and examples of the observed soot particles. Figure 5 shows images of individual particles collected on the fine and coarse filters. It demonstrates the presence of typical ring and open soot clusters that were

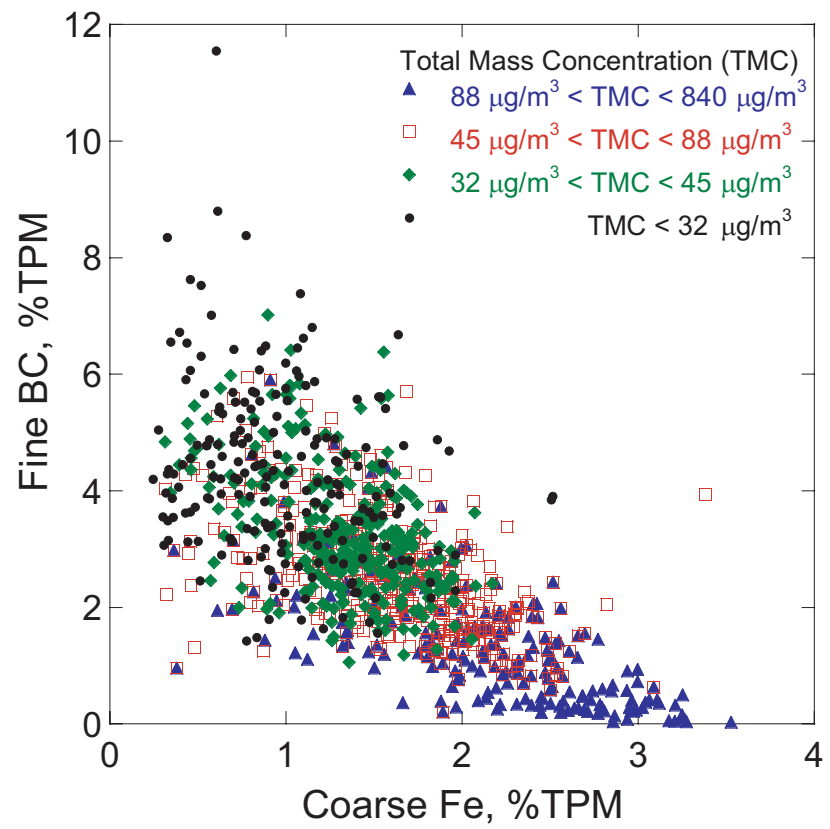

Fig. 4. BC, \% TPM in the fine size fraction versus Fe, \% TPM in the coarse size fraction. Different symbols indicate different ranges of total mass concentration.

found among dust particles on the coarse filter from the dust event on 2 April 2000, and soot clusters attached to dust that were found on the fine filter from the dust event on 3 February 2001. Quite similar pictures were observed on other analyzed filters, where soot clusters were observed between mineral dust particles, as well as attached to dust particles.

\subsection{Data integration}

A combined data set was created for the purpose of deriving relationship between aerosol spectral absorption and chemical composition. A challenge in the creation of an adequate data set was the adjustment between optical measurements made through the total atmospheric column and aerosol sampling at ground level. Representativeness of surface sampling for dust events is problematic due to the fact that dust maybe transported at high altitudes (Hamonou et al., 1999; di Sarra et al., 2001; Tsidulko et al., 2002; Dulac and Chazette, 2003; Alpert et al., 2004) and not be adequately sampled at the surface. An additional problem is that the aerosolsampling unit collects particles during two or three days on one filter, thus it may contain particles from different events and sources. In order to avoid involving filters that contain particles from different events, a time series of AOT was analyzed for each preliminarily selected episode of elevated AOT. Data were selected only if the AOT time series indicated one dust or pollution episode during the two or three day period of sampling. 


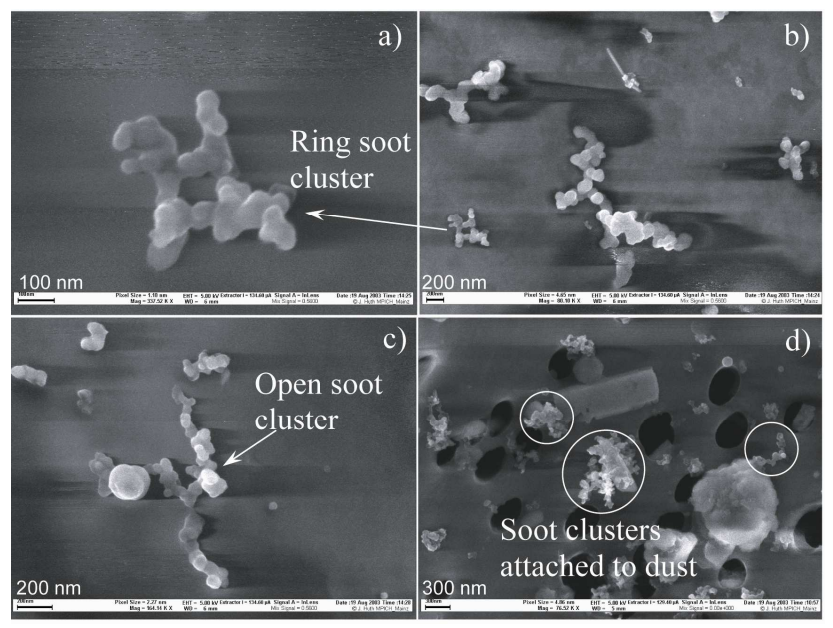

Fig. 5. Scanning electron microscope images of individual particles (a), (b), (c) demonstrate the presence of typical ring and open soot clusters that were found among dust particles on the coarse filter from the dust event on 2 April 2000, and (d) soot clusters attached to dust that were found on the fine filter from the dust event on 3 February 2001.

An additional analysis was conducted to assure representative surface sampling of dust events $(\stackrel{a}{<}<0.6)$. This analysis employs the ratio of $\tau_{\text {ext }} / \sigma_{\text {scatt } 0}$ as a function of time, where $\tau_{\text {ext }}$ is aerosol optical thickness measured through the entire atmospheric column and $\sigma_{\text {scatt } 0}$ is the aerosol scattering coefficient measured by the nephelometer at ground level. This ratio can be used for estimating the equivalent aerosol height or thickness of the aerosol layer, while its time series reflects vertical dynamics of aerosols passing over the site. For example, if the main aerosol concentration is near the surface or aloft, the value of the ratio will be low or high. In the case of homogeneous vertical aerosol distribution, this will indicate the thickness of the aerosol layer. In the case of aerosol vertical non-homogeneity, this will indicate an equivalent aerosol height. More detailed discussion and examples of the ratio $\tau_{\text {ext }} / \sigma_{\text {scatt0 }}$ usage can be found in (Derimian et al., 2006). Thus, by parallel analysis of the ratio $\tau_{\text {ext }} / \sigma_{\text {scatt } 0}$ and $\tau_{\text {ext }}$ as a function of the time, we are able to follow the dynamics of dust events and to distinguish between high altitude dust transport and dust settling episodes. This tool enables the selection of representative filters where chemical characteristics of settled dust were expected to reflect the measured optical properties. Based on the knowledge that pollution aerosols in the study area are generally transported at lower heights (Formenti et al., 2001; 2002a; 2002b) and surface sampling is representative for them, events with å $>0.7$ were not subjected to additional analysis for vertical dynamics.

Figure 6 presents averaged values of the difference SSA(440)-SSA(1020) versus the Ångström exponent (870440) for 25 selected events that cover a wide range of optical data measured during elevated loadings of dust and pollu-

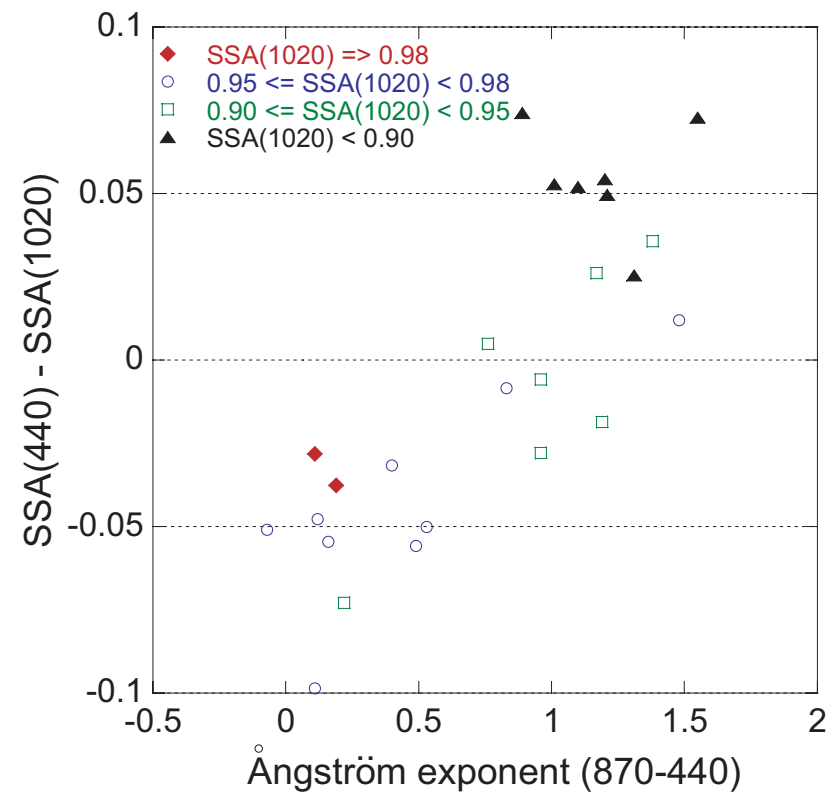

Fig. 6. Averaged values of the difference SSA(440)-SSA(1020) versus the Ångström exponent for 25 selected events measured during elevated loadings of dust and pollution aerosols. The presented data set was matched to the data set on aerosol chemistry.

tion aerosols. This optical data set was matched with aerosol chemistry and selected from the general data set (Figs. 2 and 3 ) by the above-mentioned criteria. Representation of the covered concentration range of the chemical elements $\mathrm{BC}$ and $\mathrm{Fe}$ is shown in Fig. 3. The selected data are marked using red circles ( $\mathrm{a}>0.7$ - increased contribution of fine particles) and squares ( $a<0.6$ - increased contribution of coarse particles), over the background of all observations. Unfortunately, optical data for extremely high BC concentrations were not available, probably due to some systematic problem such as meteorological conditions, or sky homogeneity that prevented sun/sky radiometer measurements, or that violated the criterion for proper almucantar retrievals. However, the existing optical data were matched to a range of points in Fig. 3 with the highest density of data, i.e., the range of most frequent concentrations. Thus, at this stage we have a set of carefully matched optical and chemical data for 25 dust and pollution loaded events.

Figure 7 presents the $\mathrm{BC}$ and $\mathrm{Fe}$ percentages in the fine and coarse size fractions and the corresponding differences: SSA(440)-SSA(1020), SSA(440)-SSA(670), and SSA(670)-SSA(1020). Data on this plot were sorted by decreasing total (fine and coarse) iron concentration. A trend from negative to positive values of SSA(440)-SSA(1020) can be noticed as the total concentration of iron decreases and the role of the $\mathrm{BC}$ contribution increases. In addition, spectral SSA subdivided by two ranges, one from $440 \mathrm{~nm}$ to $670 \mathrm{~nm}$ and the second from $670 \mathrm{~nm}$ to $1020 \mathrm{~nm}$, reveals the response to relative contributions of iron and $\mathrm{BC}$. 


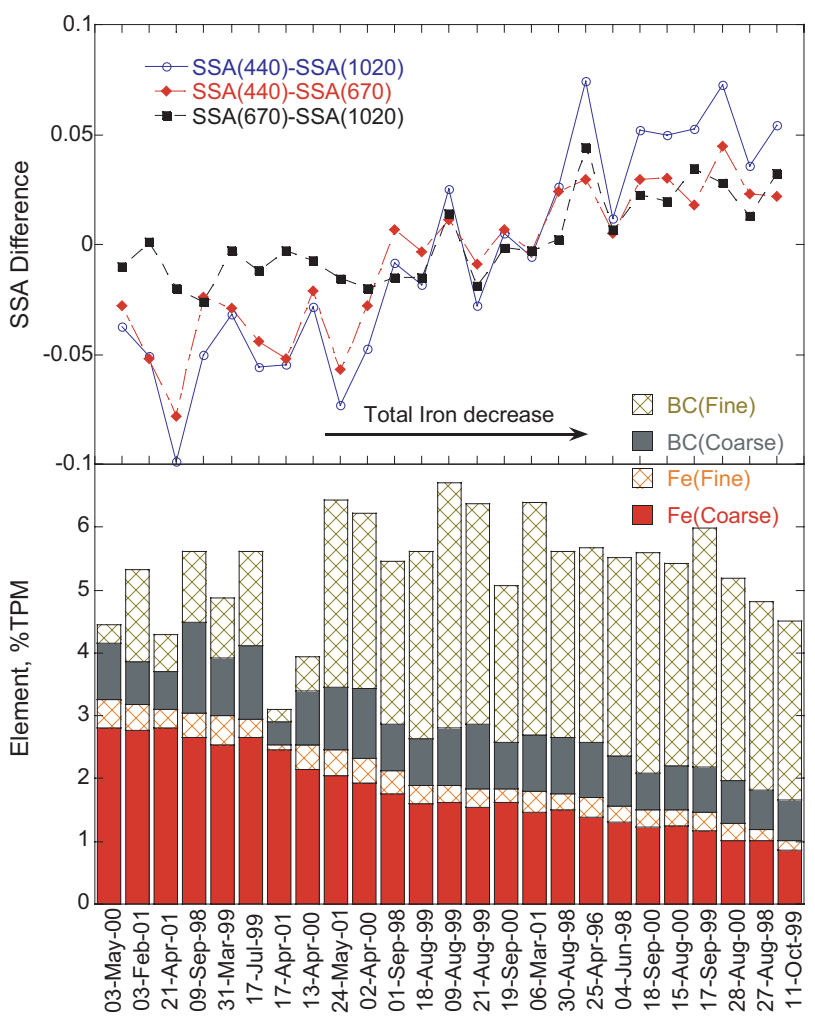

Fig. 7. $\mathrm{BC}$ and $\mathrm{Fe}$ percentage of the total particulate mass in the fine and coarse size fractions for 25 selected events and the corresponding differences of SSA(440)-SSA(1020), SSA(440)SSA(670), and SSA(670)-SSA(1020). The data are sorted by decreasing total iron concentration.

The difference SSA(440)-SSA(670) shows negative values in response to dominant iron contribution and gradually becomes positive as the role of BC increases. The SSA(670)SSA(1020) response is similar to SSA(440)-SSA(670) and SSA(440)-SSA(1020) only when the contribution of BC is high, however it varies little and is close to zero when the iron contribution is dominant. This implies that spectral SSA from $440 \mathrm{~nm}$ to $670 \mathrm{~nm}$ responded to both iron and $\mathrm{BC}$, while spectral SSA from $670 \mathrm{~nm}$ to $1020 \mathrm{~nm}$ generally responded to BC. Figure 7 also shows that the major concentration of iron is in the coarse size fraction, which supports its mineral dust origin, while most of $\mathrm{BC}$ is in the fine fraction, which is typical for anthropogenic pollution. In summary, Fig. 7 reveals that SSA retrievals from AERONET are consistent with aerosol chemical composition and suggests a potential for deriving a relationship between retrieved SSA, Fe, and $\mathrm{BC}$.

\subsection{Development of relationship equation}

The matched data set was employed for deriving the coefficients of a relationship equation which ties spectral SSA with the $\mathrm{Fe}$ and $\mathrm{BC}$ percentage in the total particulate mass. The developed relationship includes the difference SSA(440)SSA(1020), which indicates spectral SSA behavior. This spectral SSA was consistent with $\mathrm{Fe}$ and $\mathrm{BC}$ concentrations, as was shown above. However, the difference alone represents only relative values and gives no information about the absolute SSA values. The ratio of the difference SSA(440)SSA(1020) to SSA(1020) carries information about the spectral SSA as well as about the absolute values. Therefore it was used for developing equations relating spectral variability of SSA with the concentrations of the absorbing elements. The ratio of SSA(440)-SSA(1020) to SSA(1020) was expressed in terms of absorption $\left(\tau_{a b s}\right)$ and extinction $\left(\tau_{\text {ext }}\right)$ optical thickness at $440 \mathrm{~nm}$ and $1020 \mathrm{~nm}$, and then modified by substituting $\tau_{\mathrm{ext}}^{1020}$ with its estimate $\tau_{\mathrm{ext}}^{1020} \approx \tau_{\mathrm{ext}}^{440} \cdot\left(\frac{440}{1020}\right)^{\stackrel{̊}{a}}=$ $\tau_{\mathrm{ext}}^{440} \cdot 0.43^{\stackrel{\circ}{a}}$. The $\tau_{\mathrm{ext}}^{1020}$ was derived from $\tau_{\mathrm{ext}}^{440}$ using the linear approximation $\ln \tau(\lambda)=\stackrel{\circ}{a} \cdot \ln (\lambda)+\beta$ of spectral dependence $\ln \tau(\lambda)$, where the coefficient $\stackrel{\circ}{a}$ is the Ångström exponent (Angstrom, 1929; O'Neill et al., 2001; Schuster et al., 2006) (here $\stackrel{a}{ }$ is estimated using 440 and $1020 \mathrm{~nm}$ ). Then, we can write as follows:

$\frac{\omega_{440}-\omega_{1020}}{\omega_{1020}}=\frac{\frac{\tau_{\mathrm{abs}}^{1020}}{\tau_{\mathrm{ext}}^{1020}}-\frac{\tau_{\mathrm{abs}}^{440}}{\tau_{\mathrm{ext}}^{400}}}{1-\frac{\tau_{\mathrm{bss}}^{102}}{\tau_{\mathrm{ext}}^{1020}}}=\frac{\frac{1}{\tau_{\mathrm{ext}}^{440}}\left(0.43^{-\stackrel{a}{a}} \cdot \tau_{\mathrm{abs}}^{1020}-\tau_{\mathrm{abs}}^{440}\right)}{1-\frac{1}{\tau_{\mathrm{ext}}^{440}} \cdot 0.43^{-\stackrel{\circ}{a}} \cdot \tau_{\mathrm{abs}}^{1020}}$.

Assuming that only $\mathrm{Fe}$ and $\mathrm{BC}$ are responsible for aerosol absorption, and that $\mathrm{Fe}$ absorption at $1020 \mathrm{~nm}$ is close to zero $\left(\tau_{\mathrm{Fe}}^{1020} \rightarrow 0\right)$, we can rewrite Eq. (2) in the following form:

$\frac{\omega_{440}-\omega_{1020}}{\omega_{1020}}=\frac{\frac{1}{\tau_{\mathrm{ext}}^{440}}\left(0.43^{-\stackrel{a}{a}} \cdot \tau_{\mathrm{BC}}^{1020}-\tau_{\mathrm{BC}}^{440}-\tau_{\mathrm{Fe}}^{440}\right)}{1-\frac{1}{\tau_{\mathrm{ext}}^{440}} \cdot 0.43^{-\stackrel{a}{a}} \cdot \tau_{\mathrm{BC}}^{1020}}$,

where $\tau_{\mathrm{BC}}$ and $\tau_{\mathrm{Fe}}$ denote absorption optical thickness due to the presence of $\mathrm{BC}$ and $\mathrm{Fe}$. Then, the extinction and absorption optical thicknesses in Eq. (3) were unified to one wavelength. Specifically, we used the linear approximation of $\ln \tau_{\mathrm{BC}}(\lambda)=\stackrel{\circ}{\mathrm{a}}_{\mathrm{BC}} \cdot \ln (\lambda)+\beta$ for the spectral dependence of the BC absorption optical thickness (where $\stackrel{\circ}{a}_{\mathrm{BC}}$ is the Ångström exponent of the $\mathrm{BC}$ absorption spectral dependence, e.g. Dubovik et al., 1998) and replaced $\tau_{\mathrm{BC}}^{1020}$ by an

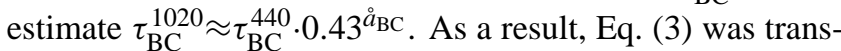
formed to the following:

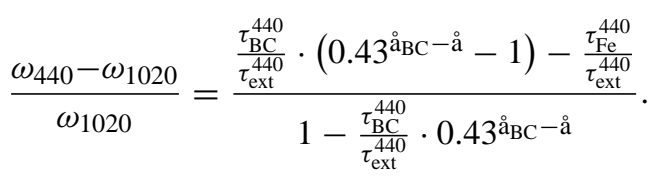

The aerosol absorption and extinction optical thickness can be represented by integrating over the entire atmospheric column of specific aerosol absorption and extinction properties known in each atmospheric layer:

$\tau_{\mathrm{abs} / \mathrm{ext}}=\int_{0}^{H} k_{\mathrm{abs} / \mathrm{ext}}^{\prime}(h) c_{\mathrm{abs} / \mathrm{total}}(h) d h$, 
where $c_{\text {abs/total }}(h)$ is the concentration of aerosol particles mass per unit of the air volume in each layer $h$, and $k_{\text {abs }}^{\prime}(h)$ and $k_{\mathrm{ext}}^{\prime}(h)$ are coefficients of specific (calculated per unit of aerosol particle mass) absorption and extinction in each atmospheric layer. Assuming that specific aerosol properties do not change vertically, i.e. $k_{\text {abs/ext }}^{\prime}(h)=\mathrm{const}=K_{\text {abs/ext }}^{\prime}$, Eq. (5) can be transformed as follows:

$$
\begin{aligned}
& \tau_{\mathrm{abs} / \mathrm{ext}}=\int_{0}^{H} k_{\mathrm{abs} / \mathrm{ext}}^{\prime}(h) c_{\mathrm{abs} / \mathrm{total}}(h) d h= \\
& K_{\mathrm{abs} / \mathrm{ext}}^{\prime} \int_{0}^{H} c_{\mathrm{abs} / \mathrm{total}}(h) d h=K_{\mathrm{abs} / \mathrm{ext}}^{\prime} C_{\mathrm{abs} / \mathrm{total}},
\end{aligned}
$$

where $C_{\text {abs/total }}$ is the $\mathrm{Fe}, \mathrm{BC}$ or total mass of the aerosol particles in the entire atmospheric column. Correspondingly, we can write:

$$
\frac{\tau_{\mathrm{Fe} / \mathrm{BC}}}{\tau_{\mathrm{ext}}}=\frac{K_{\mathrm{Fe} / \mathrm{BC}}^{\prime}}{K_{\mathrm{ext}}^{\prime}} \frac{C_{\mathrm{Fe} / \mathrm{BC}}}{C_{\text {total }}} .
$$

Making an additional assumption that the Fe and BC percentage of the total particulate mass is constant with altitude, i.e.

$$
\frac{c_{\mathrm{Fe}}(h)}{c_{\text {total }}(h)}=\text { const }(\mathrm{Fe} \%) \text { and } \frac{c_{\mathrm{BC}}(h)}{c_{\text {total }}(h)}=\text { const }(\mathrm{BC} \%) \text {, }
$$

we can rewrite Eq. (7) as follows:

$$
\frac{\tau_{\mathrm{Fe} / \mathrm{BC}}}{\tau_{\mathrm{ext}}}=\frac{K_{\mathrm{Fe} / \mathrm{BC}}^{\prime}}{K_{\mathrm{ext}}^{\prime}} \frac{c_{\mathrm{Fe} / \mathrm{BC}}(h)}{c_{\text {total }}(h)} .
$$

Using this, the relationships in Eq. (4) can be expressed via specific aerosol absorption and extinction characteristics, and mass concentrations known at any atmospheric altitude, for example as:

$$
\begin{aligned}
& \frac{\omega_{440}-\omega_{1020}}{\omega_{1020}}= \\
& \frac{\frac{K_{\mathrm{BC}}^{\prime} 440}{K_{\mathrm{ext}}^{\prime 440}} \cdot \frac{c_{\mathrm{BC}}\left(h_{0}\right)}{c_{\text {total }}\left(h_{0}\right)} \cdot\left(0.43^{\mathrm{a} \mathrm{BC}-\mathrm{a}}-1\right)-\frac{K_{\mathrm{Fe}}^{\prime} 440}{K_{\mathrm{ext}}^{\prime} 440} \cdot \frac{c_{\mathrm{Fe}}\left(h_{0}\right)}{c_{\mathrm{total}}\left(h_{0}\right)}}{1-\frac{K_{\mathrm{BC}}^{\prime 440}}{K_{\mathrm{ext}}^{\prime 440}} \cdot \frac{c_{\mathrm{BC}}\left(h_{0}\right)}{c_{\text {total }}\left(h_{0}\right)} \cdot 0.43^{\stackrel{\circ}{\mathrm{BC}}-\mathrm{a}}},
\end{aligned}
$$

see also Alfaro et al. (2004). Here $c_{\mathrm{Fe}}\left(h_{0}\right), c_{\mathrm{BC}}\left(h_{0}\right)$ and $c_{\text {total }}\left(h_{0}\right)$ are the concentrations of the $\mathrm{Fe}, \mathrm{BC}$ and total particulate mass at the near surface layer.

Thus, Eq. (10) allowed us to use the ratios of $\frac{c_{\mathrm{Fe}}\left(h_{0}\right)}{c_{\text {total }}\left(h_{0}\right)}$ and $\frac{c_{\mathrm{BC}}\left(h_{0}\right)}{c_{\text {total }}\left(h_{0}\right)}$ corresponding to the fractions of $\mathrm{Fe}$ and $\mathrm{BC}$ in the total particulate mass sampled at the surface level. The specific extinction $K_{\text {ext }}^{\prime 440}$ can be estimated as $K_{\mathrm{ext}}^{\prime 440}=\tau_{\mathrm{ext}}^{440} \cdot C_{\text {total }}^{-1}$, where $\tau_{\text {ext }}^{440}$ is directly measured by
AERONET sun-photometers, and $C_{\text {total }}$ is the total column aerosol concentration. The total column aerosol volume concentration $\left(C_{\text {Vtotal }}\right)$ (calculated as aerosol particles volume in the entire atmospheric column with a unit cross-section area) is a product of the AERONET inversion. The volume concentration can be converted to the mass concentration as $C_{\text {total }}=C_{\text {Vtotal }} \cdot \rho_{\text {total }}$, where $\rho_{\text {total }}$ is aerosol particles density. Then Eq. (10) can be rewritten as follows:

$$
\begin{aligned}
& \frac{\omega_{440}-\omega_{1020}}{\omega_{1020}}=
\end{aligned}
$$

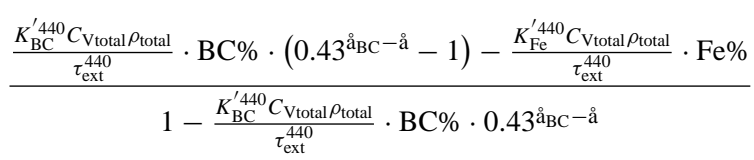

The values of $\stackrel{\circ}{\mathrm{BC}}_{\mathrm{BC}}$ and $\rho_{\text {total }}$ can be selected from values presented in the literature. Thus, all parameters in Eq. (11), except for $K_{\mathrm{BC}}^{\prime 440}$ and $K_{\mathrm{Fe}}^{\prime 440}$, are the known characteristics or are provided from available measurements. Correspondingly, if we assume that the absorption properties of BC and $\mathrm{Fe}$ (expressed via $K_{\mathrm{BC}}^{\prime} 440$ and $K_{\mathrm{Fe}}^{\prime 440}$ ) do not change for observations at the given site with its constant sources, then we can use Eq. (11) in a multivariate regression analysis for the estimation of $K_{\mathrm{BC}}^{\prime 440}$ and $K_{\mathrm{Fe}}^{\prime \prime 40}$. Specifically, one can fit the measurements of spectral SSA using Eq. (11) as a physical model with unknown coefficients $K_{\mathrm{BC}}^{\prime} 440$ and $K_{\mathrm{Fe}}^{\prime} 440$. The correctly fitted values of $K_{\mathrm{BC}}^{\prime} 440$ and $K_{\mathrm{Fe}}^{\prime} 440$ should reproduce the variability of SSA observed in a redundant measurement set (the number of measured SSA $\gg 2$ ). Once the coefficients $K_{\mathrm{BC}}^{\prime} 440$ and $K_{\mathrm{Fe}}^{\prime 440}$ are derived, they can be used for estimating $\mathrm{Fe} \%$ and $\mathrm{BC} \%$ from measured SSA, $\tau_{\mathrm{ext}}^{440}, \stackrel{\circ}{a}$ and $C_{\text {Vtotal }}$ in each single aerosol event. With that purpose one can use the following transformations of Eq. (11). The equation for estimation of $\mathrm{Fe} \%$ can be rewritten as

$$
\begin{aligned}
& \mathrm{Fe} \%=
\end{aligned}
$$

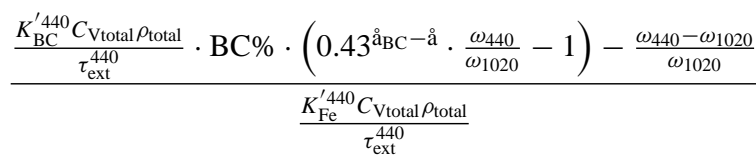

The expression for estimation of $\mathrm{BC} \%$ can also be presented as

$$
\mathrm{BC} \%=\frac{\frac{K_{\mathrm{Fe}}^{\prime 440} C_{\mathrm{Vtotal}} \rho_{\mathrm{total}}}{\tau_{\mathrm{ext}}^{440}} \cdot \mathrm{Fe} \%+\frac{\omega_{440}-\omega_{1020}}{\omega_{1020}}}{\frac{K_{\mathrm{BC}}^{\prime 440} C_{\mathrm{Vtotal}} \rho_{\mathrm{total}}}{\tau_{\mathrm{ext}}^{440}} \cdot\left(0.43^{\mathrm{a}} \mathrm{BC}-\stackrel{\mathrm{a}}{a^{2}} \cdot \frac{\omega_{440}}{\omega_{1020}}-1\right)} .
$$

It should be noted that the SSA and its spectral dependence is sensitive not only to changes in aerosol composition, but also to the variability in aerosol size distribution (Dubovik et al., 1998). This can explain the fact that the Ångström exponent of extinction is included in Eq. (11) as a parameter to 
account for the SSA spectral variability caused by changes in size distribution. It is also important to note that $\mathrm{BC}$ absorption spectral dependence (included in Eq. (11) via Ångström exponent) can be different for different types of BC. However, we assume that the aerosols observed in the current study contain similar types of BC. Correspondingly, we implemented a series of fits with different values of $\stackrel{\circ}{\mathrm{BC}}_{\mathrm{BC}}$ and have chosen the one value $\left(\stackrel{\circ}{\mathrm{BC}}_{\mathrm{BC}}=0.8\right)$ that yielded the highest fitted correlation coefficient. Although it differs from the commonly used value of one, it is still in the range of possible values presented in the literature, e.g., (Kirchstetter et al., 2004). Since, in our case, the bulk material was dust, we utilized the density of dust and assumed $\rho_{\text {total }}$ of $1 \mathrm{~g} \mathrm{~cm}^{-1}$ e.g., (Cattle et al., 2002). However, the dust density may vary in the range from around 1 to $2 \mathrm{~g} \mathrm{~cm}^{-1}$, e.g., (Sugimae, 1984; Mamane and Dzubay, 1988; Simonson, 1995; Seinfeld et al., 2004; Menendez et al., 2007).

The performed multivariate regression analysis of Eq. (11) yielded $\quad K_{\mathrm{BC}}^{\prime} 440=0.037 \pm 0.008$ and $K_{\mathrm{Fe}}^{\prime 440}=0.013 \pm 0.005$ ( \pm Standard Error). Note that by using BC and Fe fractions instead of percentages in Eq. (11), the derived specific mass absorptions are: $K_{\mathrm{BC}}^{\prime 440}=3.7 \mathrm{~m}^{2} \mathrm{~g}^{-1}$, and $K_{\mathrm{Fe}}^{\prime 440}=1.3 \mathrm{~m}^{2} \mathrm{~g}^{-1}$. The regression is significant at $p<0.0001$, the fitted correlation coefficient is 0.74 , and the coefficient of multiple determination $\left(r^{2}\right)$ is 0.55 . This means that $\mathrm{Fe}, \mathrm{BC}, \tau_{\mathrm{ext}}^{440}, \stackrel{\circ}{a}$ and $C_{\text {total }}$ in this model explain $55 \%$ of the variance in the spectral single scattering albedo. The rest of the variance may be explained by the following facts: (i) Fe is not directly related to the optically relevant iron oxide (Lafon et al., 2004), (ii) other components of mineral dust may contribute to dust absorption (Jacobson, 2001), (iii) spectral absorption of pollution cannot be completely explained by measured BC, (Bond, 2001; Kirchstetter et al., 2004), and (iv) measurement uncertainties.

For the purposes of comparison, the $K_{\mathrm{BC}}^{\prime 440}$ and $K_{\mathrm{Fe}}^{\prime 440}$ were also estimated using Mie theory calculations. For instance, the specific mass absorptions, calculated by Mie theory, were $4.7 \mathrm{~m}^{2} \mathrm{~g}^{-1}$ for $\mathrm{BC}$ and $1.3 \mathrm{~m}^{-2} \mathrm{~g}$ for Fe. The refractive index at $440 \mathrm{~nm}$ used in the Mie calculations for BC was $m=1.76-$ $0.45 i$ (Shettle and Fenn, 1979), and for Fe it was $m=3-0.2 i$ (Jennings, 1993). Here, we also used a $\rho_{\mathrm{BC}}=2.26 \mathrm{~g} \mathrm{~cm}^{-1}$ (Hess and Herd, 1993) and a $\rho_{\mathrm{Fe}}=5.24 \mathrm{~g} \mathrm{~cm}^{-1}$ (Sugimae, 1984) for converting volume to mass concentrations. Thus, the $K_{\mathrm{BC}}^{\prime 440}$ and $K_{\mathrm{Fe}}^{\prime 440}$ derived by the regression equation and by the Mie calculations were in agreement. The obtained values also remained comparable and of the same order of magnitude as when we varied the assumed refractive indices and aerosol densities over a possible range. Therefore, considering all the assumptions, the agreement obtained is encouraging.

A drawback of the above model is that this approach requires information on $\mathrm{BC}$ in order to derive the $\mathrm{Fe}$ concentration, and vice-versa. However, for example, a recent study on inversion of AERONET retrievals into BC concentrations (Schuster et al., 2005; Dey et al., 2006) can be employed for completing this information. Thus AERONET retrievals can be utilized for deriving both, $\mathrm{BC}$ and $\mathrm{Fe}$ concentrations.

\subsection{Evaluation of the derived relationship}

In order to evaluate our attempt to assess the Fe concentration, we utilized AERONET retrievals from several locations (Table 1). For some of these locations the Fe concentrations had been reported in the literature and were available for comparison. Specifically, we used an average of all available data from several years from the following sites: Sede Boker, Israel; Solar Village, Saudi Arabia; and Bahrain, Persian Gulf. For the Dunhuang site in China, average values observed during the ACE-Asia field campaign (AprilMay 2001) were used. For the Capo Verde and Dakar sites in North-western Africa, average values for about ten years of observations, during the dust-dominated season of AprilNovember, were used. An accumulated error was estimated in order to assess the uncertainty in the calculated Fe percentage. This error is caused by uncertainty in the variables

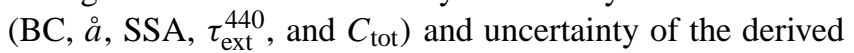
relationship (i.e., errors of the regression coefficients). Since measured concentrations of BC were not available, they were assumed to be $3 \pm 0.3 \%$ for the Middle East region (based on existing data for the Sede Boker site), and $1 \pm 0.1 \%$ for locations and periods where strong contamination was not expected. The error for $\stackrel{\AA}{a}$ was estimated as 0.1 . The error of the SSA was assumed to be 0.03 , which is the reported error of the SSA values (Dubovik et al., 2002a). However, for events with high aerosol optical thickness, the SSA accuracy can increase up to 0.01 . The reported error of $\tau_{\mathrm{ext}}^{440}$ measurements by AERONET is 0.01 . The error of $C_{\text {tot }}$ was estimated as being $5 \%$.

The calculated percentages of $\mathrm{Fe}$ for several locations are presented in Table 1 for the assumed BC concentrations, and accompanied by the standard errors representing SSA accuracy of \pm 0.03 and \pm 0.01 . These errors were in the range of $\pm 41 \%$ to $58 \%$ for the worst-case scenarios'. However, if SSA accuracy could be improved up to \pm 0.01 , the errors of calculated $\mathrm{Fe}$ concentration would range between $\pm 33 \%$ to $38 \%$. In Table 1 the calculated percentages of Fe are compared with values reported in the literature. For example, Ganor and Foner (1996) gave a median Fe content of 2.9\% for dust storms in Israel. This value is a result of completely independent measurements, and reasonably agrees with the value of $2.4 \pm 1.4 \%$ calculated by the derived equation. The calculated Fe percentage for the Dunhuang site in China during ACE-Asia of $3.1 \pm 1.4 \%$ is comparable to the observed value of $4.0 \pm 0.9 \%$ (Zhang et al., 2003). The calculated Fe percentage of $6.2 \pm 2.6 \%$ and $5.2 \pm 2.3 \%$ for Capo Verde and Dakar in North-western Africa are comparable to the value reported by Lafon et al. (2004), who found a mean $\mathrm{Fe}$ value of $6.3 \pm 0.9 \%$ in Niger, where the probable source was the Chad basin. It is also fairly comparable to the value of $4.45 \pm 0.49 \%$ (Guieu et al., 2002), which was proposed as 
Table 1. Reported in literature and calculated percentage of Fe in total particulate mass (TPM) for several locations with dust-dominated conditions, and corresponding measured spectral single-scattering albedo $\left(\omega_{0}\right)$, Ångström exponent (aa), aerosol optical thickness $\left(\tau_{\text {ext }}\right)$, and column volume concentration $\left(C_{\mathrm{Vtotal}}\right)$. Calculated $\mathrm{Fe}$ is for an assumed BC percentage and accompanied by an error assessed for the SSA accuracy of \pm 0.03 and \pm 0.01 , respectively.

\begin{tabular}{|c|c|c|c|c|c|c|c|c|}
\hline & \multicolumn{5}{|c|}{ Measured values } & \multirow{2}{*}{$\frac{\text { Assumed }}{\text { BC, \% ТPM }}$} & \multirow{2}{*}{$\begin{array}{l}\text { Calculated } \\
\text { Fe, \% TPM }\end{array}$} & \multirow{2}{*}{$\begin{array}{l}\text { Reported in literature } \\
\mathrm{Fe}, \% \mathrm{TPM}\end{array}$} \\
\hline & $\omega_{0}^{440}$ & $\omega_{0}^{1020}$ & å & $\tau_{\mathrm{ext}}^{440}$ & $\begin{array}{l}C_{\mathrm{Vtotal}} \\
\mu \mathrm{m}^{3} \mu \mathrm{m}^{-2}\end{array}$ & & & \\
\hline $\begin{array}{l}\text { Sede Boker, Israel, } \\
\text { Middle East }\end{array}$ & 0.91 & 0.96 & 0.24 & 0.58 & 0.40 & 3 & $2.4( \pm 1.4 \pm 0.9)$ & 2.9 (Ganor and Foner, 1996) \\
\hline $\begin{array}{l}\text { Solar Village, Saudi Arabia, } \\
\text { Middle East }\end{array}$ & 0.90 & 0.97 & 0.22 & 0.59 & 0.43 & 3 & $4.1( \pm 1.7 \pm 1.4)$ & - \\
\hline Bahrain, Middle East & 0.90 & 0.97 & 0.32 & 0.63 & 0.42 & 3 & $4.5( \pm 1.9 \pm 1.5)$ & - \\
\hline $\begin{array}{l}\text { Dunhuang, China, Asia } \\
\text { (April-May 2001) }\end{array}$ & 0.93 & 0.98 & 0.04 & 0.97 & 0.85 & 1 & $3.1( \pm 1.4 \pm 1.1)$ & $4.0 \pm 0.9$ (Zhang et al., 2003) \\
\hline $\begin{array}{l}\text { Capo Verde, Atlantic, } \\
\text { North-western Africa } \\
\text { (April-November) }\end{array}$ & 0.91 & 0.97 & 0.18 & 0.63 & 0.41 & 1 & $6.2( \pm 2.6 \pm 2.4)$ & $\begin{array}{l}4.45 \pm 0.49 \text { (Guieu et al., 2002) } \\
6.3 \pm 0.9 \text { (Lafon et al., 2004) }\end{array}$ \\
\hline $\begin{array}{l}\text { Dakar, Senegal, } \\
\text { North-western Africa } \\
\text { (April-November) }\end{array}$ & 0.91 & 0.96 & 0.20 & 0.67 & 0.42 & 1 & $5.2( \pm 2.3 \pm 2.0)$ & \\
\hline
\end{tabular}

characterizing Saharan dust. However, it is lower than the reported $7.8 \pm 0.4 \%$ in the Sahelian zone (Lafon et al., 2004). In summary, the calculated percentages of Fe and those reported in the literature appear comparable. Considering the agreement between the calculated results and the results reported in the literature, one may also expect improvement of modeling accuracy by the presented approach with increasing number and quality of observations.

One additional aspect should be discussed here for the proper interpretation of the results obtained. That is, how representative is the total iron concentration for the iron oxide content of the aerosol? Iron oxide is present as a major aerosol component affecting the short-wavelength absorption of mineral dust. However, iron oxide represents only part of the total iron, which may also exist in the crystal lattice of numerous other desert minerals. The iron oxide-to-total iron ratio in natural and soil-derived aerosols was characterized by (Lafon et al., 2004; 2006). They reported considerable variability in the iron oxide-to-total iron ratio for various regions and sampling conditions. Lafon et al. (2006), however, conclude that there is no clear relationship between the oxide-to-total iron ratio and dust origin or aging; though, both effects probably play a role, and additional studies are required. Based on all the values for the oxide-to-total iron ratio reported in (Lafon et al., 2004; 2006) we calculated an average of $0.54( \pm 0.10)$ ( \pm Std. Dev.). This variability can be reduced by removing the largest outliers, therefore a vari- ability of that level or lower may be expected for the ratio at a regional scale. Thus, given the present lack of knowledge, we concluded that a fixed oxide-to-total iron ratio is an acceptable assumption for the conducted analysis of the regional aerosol observations.

\section{Summary and conclusions}

The importance of the radiative and biogeochemical impact of iron on the climate system requires the estimation of the iron distribution, especially in regions of the globe that are strongly affected by mineral dust. The observed mixtures of dust and pollution aerosols over the Negev desert of Israel enabled the characterization of the relationship between spectral absorption and chemical composition. We have presented the response of remotely sensed aerosol spectral absorption to varying iron concentrations, and suggested an approach for the estimation of the iron content of the dust aerosol. The following is a summary of specific conclusions inferred in this study.

1. Mineral-dust-derived Fe (mostly in the coarse size fraction) and pollution-originated BC (mainly in the fine fraction) were found to be supplied to the Negev desert from different sources. Individual particle analysis of some dust events demonstrated the presence of typical 
ring and open soot clusters, both externally-mixed and attached to dust particles.

2. The difference SSA(440)-SSA(1020), which indicates SSA spectral behavior, showed a trend from negative (stronger absorption in $440 \mathrm{~nm}$ ) to positive (stronger absorption in $1020 \mathrm{~nm}$ ) values as the total iron concentration decreased and the role of $\mathrm{BC}$ increased.

3. While the suggested approach should be validated under different conditions in order to assure the consistency of the method, the presented results are encouraging and support the validity of the approach. The accuracy of the presented method can be improved with higher quality and increased number of observations.

An advantage of the derived relationship is the use of actual ambient aerosol measurements, namely, the retrieved spectral absorption from the total column, and in-situ $\mathrm{Fe}$ and $\mathrm{BC}$ concentrations. Such an approach does not involve modeling of aerosol composition and optical characteristics. The approach suggested here may be employed for the estimation of the iron concentration in mineral dust, and further may enable quantification of the iron distribution and deposition during dust storm events.

Acknowledgements. The authors thank all members of the AERONET group, led by Brent N. Holben, for data processing and operation of the AERONET sites. In addition we thank the principle investigators Didier Tanré, Naif Al-Abbadi, and their staff for establishing and maintaining Capo Verde, Dakar and Solar Village sites used in this investigation. The filter analysis was supported by the Belgian Federal Science Policy Office. The authors are thankful to Joachim Huth from the Max Planck Institute for Chemistry, Mainz, Germany, for the SEM images. Also, we appreciate thoughtful and constructive comments made by reviewers G. Schuster, P. Fialho and J. Barnard, which contributed to significant improvement of the paper.

Edited by: R. Volkamer

\section{References}

Alfaro, S. C., Lafon, S., Rajot, J. L., Formenti, P., Gaudichet, A., and Maille, M.: Iron oxides and light absorption by pure desert dust: An experimental study, J. Geophys. Res., 109, D08208, doi:10.1029/2003JD004374, 2004.

Alpert, P., Kishcha, P., Shtivelman, A., Krichak, S. O., and Joseph, J. H.: Vertical distribution of Saharan dust based on 2.5-year model predictions, Atmos. Res., 70, 109-130, 2004.

Andreae, M. O. and Gelencser, A.: Black carbon or brown carbon? The nature of light-absorbing carbonaceous aerosols, Atmos. Chem. Phys., 6, 3131-3148, 2006, http://www.atmos-chem-phys.net/6/3131/2006/.

Andreae, T. W., Andreae, M. O., Ichoku, C., Maenhaut, W., Cafmeyer, J., Karnieli, A., and Orlovsky, L.: Light scattering by dust and anthropogenic aerosol at a remote site in the Negev desert, Israel, J. Geophys. Res., 107, 4008, doi:4010.1029/2001JD900252, 2002.
Angstrom, A.: On the atmospheric transmission of sun radiation and on dust in the air, Geogr. Ann., 11, 156-166, 1929.

Behrenfeld, M. J., Bale, A. J., Kolber, Z. S., Aiken, J., and Falkowski, P. G.: Confirmation of iron limitation of phytoplankton photosynthesis in the equatorial pacific ocean, Nature, 383, 508-511, 1996.

Bond, T. C.: Spectral dependence of visible light absorption by carbonaceous particles emitted from coal combustion, Geophys. Res. Lett., 28, 4075-4078, 2001.

Bond, T. C., Streets, D. G., Yarber, K. F., Nelson, S. M., Woo, J. H., and Klimont, Z.: A technology-based global inventory of black and organic carbon emissions from combustion, J. Geophys. Res., 109, D14203, doi:10.1029/2003JD003697, 2004.

Bond, T. C. and Bergstrom, R. W.: Light absorption by carbonaceous particles: An investigative review, Aerosol Science and Technology, 40, 27-67, 2006.

Boyd, P. W., Watson, A. J., Law, C. S., Abraham, E. R., Trull, T., Murdoch, R., Bakker, D. C. E., Bowie, A. R., Buesseler, K. O., Chang, H., Charette, M., Croot, P., Downing, K., Frew, R., Gall, M., Hadfield, M., Hall, J., Harvey, M., Jameson, G., LaRoche, J., Liddicoat, M., Ling, R., Maldonado, M. T., McKay, R. M., Nodder, S., Pickmere, S., Pridmore, R., Rintoul, S., Safi, K., Sutton, P., Strzepek, R., Tanneberger, K., Turner, S., Waite, A., and Zeldis, J.: A mesoscale phytoplankton bloom in the polar southern ocean stimulated by iron fertilization, Nature, 407, 695702, 2000.

Broecker, W. S. and Henderson, G. M.: The sequence of events surrounding Termination II and their implications for the cause of glacial-interglacial $\mathrm{CO}_{2}$ changes, Paleoceanography, 13, 352364, 1998.

Capone, D. G., Zehr, J. P., Paerl, H. W., Bergman, B., and Carpenter, E. J.: Trichodesmium, a globally significant marine cyanobacterium, Science, 276, 1221-1229, 1997.

Cattle, S. R., McTainsh, G. H., and Wagner, S.: Ae olian dust contributions to soil of the Namoi Valley, Northern NSW, Australia, Catena, 47, 245-264, 2002.

Chung, S. H. and Seinfeld, J. H.: Climate response of direct radiative forcing of anthropogenic black carbon, J. Geophys. Res., 110, D11102, doi:10.1029/2004JD005441, 2005.

Coale, K. H., Johnson, K. S., Fitzwater, S. E., Gordon, R. M., Tanner, S., Chavez, F. P., Ferioli, L., Sakamoto, C., Rogers, P., Millero, F., Steinberg, P., Nightingale, P., Cooper, D., Cochlan, W. P., Landry, M. R., Constantinou, J., Rollwagen, G., Trasvina, A., and Kudela, R.: A massive phytoplankton bloom induced by an ecosystem-scale iron fertilization experiment in the equatorial Pacific Ocean, Nature, 383, 495-501, 1996.

Colarco, P. R., Toon, O. B., Reid, J. S., Livingston, J. M., Russell, P. B., Redemann, J., Schmid, B., Maring, H. B., Savoie, D., Welton, E. J., Campbell, J. R., Holben, B. N., and Levy, R.: Saharan dust transport to the Caribbean during PRIDE: 2. Transport, vertical profiles, and deposition in simulations of in situ and remote sensing observations, J. Geophys. Res., 108(D19), 8589, doi:10.1029/2002JD002658, 2003.

Derimian, Y., Karnieli, A., Kaufman, Y. J., Andreae, M. O., Andreae, T. W., Dubovik, O., Maenhaut, W., Koren, I., and Holben, B. N.: Dust and pollution aerosols over the Negev Desert, Israel: Properties, transport, and radiative effect, J. Geophys. Res.Atmos., 111, D05205, doi:05210.01029/02005JD006549, 2006.

Dey, S., Tripathi, S. N., Singh, R. P., and Holben, B. N.: Retrieval of 
black carbon and specific absorption over Kanpur City, Northern India during 2001-2003 using aeronet data, Atmos. Environ., 40, 445-456, 2006.

di Sarra, A., Di Iorio, T., Cacciani, M., Fiocco, G., and Fua, D.: Saharan dust profiles measured by lidar at Lampedusa, J. Geophys. Res., 106, 10 335-10347, 2001.

Dubovik, O., Holben, B. N., Kaufman, Y. J., Yamasoe, M., Smirnov, A., Tanre, D., and Slutsker, I.: Single-scattering albedo of smoke retrieved from the sky radiance and solar transmittance measured from ground, J. Geophys. Res., 103, 31 903-31 923, 1998.

Dubovik, O. and King, M. D.: A flexible inversion algorithm for retrieval of aerosol optical properties from sun and sky radiance measurements, J. Geophys. Res., 105, 20 673-20 696, 2000.

Dubovik, O., Smirnov, A., Holben, B. N., King, M. D., Kaufman, Y. J., Eck, T. F., and Slutsker, I.: Accuracy assessments of aerosol optical properties retrieved from Aerosol Robotic Network (AERONET) sun and sky radiance measurements, J. Geophys. Res., 105, 9791-9806, 2000.

Dubovik, O., Holben, B., Eck, T. F., Smirnov, A., Kaufman, Y. J., King, M. D., Tanre, D., and Slutsker, I.: Variability of absorption and optical properties of key aerosol types observed in worldwide locations, J. Atmos. Sci., 59, 590-608, 2002a.

Dubovik, O., Holben, B. N., Lapyonok, T., Sinyuk, A., Mishchenko, M. I., Yang, P., and Slutsker, I.: Non-spherical aerosol retrieval method employing light scattering by spheroids, Geophys. Res. Lett., 29, 1415, doi:10.1029/2001GL014506, 2002b.

Dubovik, O., Sinyuk, A., Lapyonok, T., Holben, B. N., Mishchenko, M., Yang, P., Eck, T. F., Volten, H., Munoz, O., Veihelmann, B., van der Zande, W. J., Leon, J. F., Sorokin, M., and Slutsker, I.: Application of spheroid models to account for aerosol particle nonsphericity in remote sensing of desert dust, J. Geophys. Res.-Atmos., 111, D11208, doi:10.1029/2005JD006619, 2006.

Dulac, F. and Chazette, P.: Airborne study of a multi-layer aerosol structure in the eastern Mediterranean observed with the airborne polarized lidar ALEX during a STAAARTE campaign (7 June 1997), Atmos. Chem. Phys., 3, 1817-1831, 2003,

http://www.atmos-chem-phys.net/3/1817/2003/.

Eck, T. F., Holben, B. N., Reid, J. S., Dubovik, O., Smirnov, A., O'Neill, N. T., Slutsker, I., and Kinne, S.: Wavelength dependence of the optical depth of biomass burning, urban, and desert dust aerosols, J. Geophys. Res.-Atmos., 104, 31 333-31 349, 1999.

Falkowski, P. G.: Evolution of the nitrogen cycle and its influence on the biological sequestration of $\mathrm{CO}_{2}$ in the ocean, Nature, 387, 272-275, 1997.

Fan, S. M., Moxim, W. J., and Levy, H.: Aeolian input of bioavailable iron to the ocean, Geophys. Res. Lett., 33, L07602, doi:10.1029/2005GL024852, 2006.

Fialho, P., Hansen, A. D. A., and Honrath, R. E.: Absorption coefficients by aerosols in remote areas: A new approach to decouple dust and black carbon absorption coefficients using sevenwavelength aethalometer data, J. Aerosol Sci., 36, 267-282, 2005.

Fialho, P., Freitas, M. C., Barata, F., Vieira, B., Hansen, A. D. A., and Honrath, R. E.: The aethalometer calibration and determination of iron concentration in dust aerosols, J. Aerosol Sci., 37, 1497-1506, 2006.
Formenti, P., Andreae, M. O., Andreae, T. W., Galani, E., Vasaras, A., Zerefos, C., Amiridis, V., Orlovsky, L., Karnieli, A., Wendisch, M., Wex, H., Holben, B. N., Maenhaut, W., and Lelieveld, J.: Aerosol optical properties and large-scale transport of air masses: Observations at a coastal and a semiarid site in the eastern Mediterranean during summer 1998, J. Geophys. Res., 106, 9807-9826, 2001.

Formenti, P., Boucher, O., Reiner, T., Sprung, D., Andreae, M. O., Wendisch, M., Wex, H., Kindred, D., Tzortziou, M., Vasaras, A., and Zerefos, C.: STAAARTE-MED 1998 summer airborne measurements over the Aegean Sea - 2. Aerosol scattering and absorption, and radiative calculations, J. Geophys. Res., 107(D21), 4451, doi:10.1029/2001JD001536, 2002a.

Formenti, P., Reiner, T., Sprung, D., Andreae, M. O., Wendisch, M., Wex, H., Kindred, D., Dewey, K., Kent, J., Tzortziou, M., Vasaras, A., and Zerefos, C.: STAAARTE-MED 1998 summer airborne measurements over the Aegean Sea - 1. Aerosol particles and trace gases, J. Geophys. Res., 107(D21), 4450, doi:10.1029/2001JD001337, 2002b.

Fung, I. Y., Meyn, S. K., Tegen, I., Doney, S. C., John, J. G., and Bishop, J. K. B.: Iron supply and demand in the upper ocean, Global Biogeochem. Cy., 14, 281-295, 2000.

Ganor, E., and Foner, H. A.: The mineralogical and chemical properties and the behaviour of aeolian Saharan dust over Israel, in: The impact of desert dust across the Mediterranean, edited by: Guerzoni, S., and Chester, R., Kluwer Academic Publishers, Printed in the Netherlands, 163-172, 1996.

Gao, Y., Kaufman, Y. J., Tanre, D., Kolber, D., and Falkowski, P. G.: Seasonal distributions of aeolian iron fluxes to the global ocean, Geophys. Res. Lett., 28, 29-32, 2001.

Gao, Y., Fan, S. M., and Sarmiento, J. L.: Aeolian iron input to the ocean through precipitation scavenging: A modeling perspective and its implication for natural iron fertilization in the ocean, J. Geophys. Res., 108(D7), 4221 doi:10.1029/2002JD002420, 2003.

Gerasopoulos, E., Andreae, M. O., Zerefos, C. S., Andreae, T. W., Balis, D., Formenti, P., Merlet, P., Amiridis, V., and Papastefanou, C.: Climatological aspects of aerosol optical properties in Northern Greece, Atmos. Chem. Phys., 3, 2025-2041, 2003, http://www.atmos-chem-phys.net/3/2025/2003/.

Guieu, C., Loye-Pilot, M. D., Ridame, C., and Thomas, C.: Chemical characterization of the Saharan dust end-member: Some biogeochemical implications for the western Mediterranean Sea, J. Geophys. Res., 107(D15), 4258, doi:10.1029/2001JD000582, 2002.

Hamonou, E., Chazette, P., Balis, D., Dulac, F., Schneider, X., Galani, E., Ancellet, G., and Papayannis, A.: Characterization of the vertical structure of Saharan dust export to the Mediterranean basin, J. Geophys. Res., 104, 22 257-22 270, 1999.

Hansen, A. D. A., Rosen, H., and Novakov, T.: The aethalometer - an instrument for the real-time measurement of opticalabsorption by aerosol-particles, Sci. Total Environ., 36, 191-196, 1984.

Hess, W. H. and Herd, C. R.: Microstructure, morphology, and general physical properties, in carbon black, in, edited by: Donnet, J., Bansal, R., and Wang, M., CRC Press, Boca Raton, Fla., 89173, 1993.

Holben, B. N., Eck, T. F., Slutsker, I., Tanre, D., Buis, J. P., Setzer, A., Vermote, E., Reagan, J. A., Kaufman, Y. J., and Naka- 
jima, T.: AERONET - A federated instrument network and data archive for aerosol characterization, Remote Sensing of Environment, 66, 1-16, 1998.

Ichoku, C., Andreae, M. O., Andreae, T. W., Meixner, F. X., Schebeske, G., Formenti, P., Maenhaut, W., Cafmeyer, J., Ptasinski, J., Karnieli, A., and Orlovsky, L.: Interrelationships between aerosol characteristics and light scattering during late winter in an Eastern Mediterranean arid environment, J. Geophys. Res., 104, 24 371-24 393, 1999.

Israelevich, P. L., Ganor, E., Levin, Z., and Joseph, J. H.: Annual variations of physical properties of desert dust over Israel, J. Geophys. Res.-Atmos., 108(D13), 4318, doi:10.1029/2002JD003163, 2003.

Jacobson, M. Z.: Global direct radiative forcing due to multicomponent anthropogenic and natural aerosols, J. Geophys. Res., 106, 1551-1568, 2001.

Jacobson, M. Z.: Climate response of fossil fuel and biofuel soot, accounting for soot's feedback to snow and sea ice albedo and emissivity, J. Geophys. Res., 109, D21201, doi:10.1029/2004JD004945, 2004.

Jennings, S. G.: Aerosol effects on climate, University of Arizona Press, Tucson, 304 pp., 1993.

Jickells, T. D., An, Z. S., Andersen, K. K., Baker, A. R., Bergametti, G., Brooks, N., Cao, J. J., Boyd, P. W., Duce, R. A., Hunter, K. A., Kawahata, H., Kubilay, N., laRoche, J., Liss, P. S., Mahowald, N., Prospero, J. M., Ridgwell, A. J., Tegen, I., and Torres, R.: Global iron connections between desert dust, ocean biogeochemistry, and climate, Science, 308, 67-71, 2005.

Johnson, K. S., Elrod, V. A., Fitzwater, S. E., Plant, J. N., Chavez, F. P., Tanner, S. J., Gordon, R. M., Westphal, D. L., Perry, K. D., Wu, J. F., and Karl, D. M.: Surface ocean-lower atmosphere interactions in the Northeast Pacific Ocean Gyre: Aerosols, iron, and the ecosystem response, Global Biogeochemical Cycles, 17, 1063, doi:10.1029/2002GB002004, 2003.

Kaufman, Y. J., Boucher, O., Tanre, D., Chin, M., Remer, L. A., and Takemura, T.: Aerosol anthropogenic component estimated from satellite data, Geophys. Res. Lett., 32, L17804, doi:10.1029/2005GL023125, 2005a.

Kaufman, Y. J., Koren, I., Remer, L. A., Tanre, D., Ginoux, P., and Fan, S.: Dust transport and deposition observed from the Terra-Moderate Resolution Imaging Spectroradiometer (MODIS) spacecraft over the Atlantic ocean, J. Geophys. Res., 110, D10S12, doi:10.1029/2003JD004436, 2005b.

Kirchstetter, T. W., Novakov, T., and Hobbs, P. V.: Evidence that the spectral dependence of light absorption by aerosols is affected by organic carbon, J. Geophys. Res., 109, D21208, doi:10.1029/2004JD004999, 2004.

Koven, C. D. and Fung, I.: Inferring dust composition from wavelength-dependent absorption in Aerosol Robotic Network (AERONET) data, J. Geophys. Res., 111, D14205, doi:10.1029/2005JD006678, 2006.

Kubilay, N., Cokacar, T., and Oguz, T.: Optical properties of mineral dust outbreaks over the northeastern Mediterranean, J. Geophys. Res., 108(D21), 4666, doi:10.1029/2003JD003798, 2003.

Lafon, S., Rajot, J. L., Alfaro, S. C., and Gaudichet, A.: Quantification of iron oxides in desert aerosol, Atmos. Environ., 38, 1211-1218, 2004.

Lafon, S., Sokolik, I. N., Rajot, J. L., Caquineau, S., and Gaudichet, A.: Characterization of iron oxides in mineral dust aerosols: Im- plications for light absorption, J. Geophys. Res., 111, D21207, doi:10.1029/2005JD007016, 2006.

Maenhaut, W., Salma, I., Cafmeyer, J., Annegarn, H. J., and Andreae, M. O.: Regional atmospheric aerosol composition and sources in the eastern Transvaal, South Africa, and impact of biomass burning, J. Geophys. Res., 101, 23 631-23 650, 1996a.

Maenhaut, W., Salomonovic, R., Cafmeyer, J., Ichoku, C., Karnieli, A., and Andreae, M. O.: Anthropogenic and natural radiatively active aerosol types at Sede Boker, Israel, J. Aerosol Sci., 27, S47-S48, 1996b.

Maenhaut, W., Cafmeyer, J., Ptasinski, J., Andreae, M. O., Andreae, T. W., Elbert, W., Meixner, F. X., Karnieli, A., and Ichoku, C.: Chemical composition and light scattering of the atmospheric aerosol at a remote site in the Negev desert, Israel, J. Aerosol Sci., 28, S73-S74, 1997.

Mahowald, N. M., Baker, A. R., Bergametti, G., Brooks, N., Duce, R. A., Jickells, T. D., Kubilay, N., Prospero, J. M., and Tegen, I.: Atmospheric global dust cycle and iron inputs to the ocean, Glob. Biogeochem. Cy., 19, GB4025, doi:10.1029/2004GB002402, 2005.

Mamane, Y. and Dzubay, T. G.: Fly-ash concentrations in philadelphia aerosol determined by electron-microscopy, Water Air and Soil Pollution, 37, 389-405, 1988.

Martin, J. H. and Gordon, R. M.: Northeast pacific iron distributions in relation to phytoplankton productivity, Deep-Sea Research Part a-Oceanographic Research Papers, 35, 177-196, 1988.

Menendez, I., Diaz-Hernandez, J. L., Mangas, J., Alonso, I., and Sanchez-Soto, P. J.: Airborne dust accumulation and soil development in the North-East sector of Gran Canaria (Canary Islands, Spain), Journal of Arid Environments, 71, 57-81, 2007.

Mishchenko, M. I., Travis, L. D., Kahn, R. A., and West, R. A.: Modeling phase functions for dustlike tropospheric aerosols using a shape mixture of randomly oriented polydisperse spheroids, J. Geophys. Res., 102, 16 831-16847, 1997.

Mongin, M., Nelson, D. M., Pondaven, P., and Treguer, P.: Simulation of upper-ocean biogeochemistry with a flexible-composition phytoplankton model: $\mathrm{C}, \mathrm{N}$ and $\mathrm{Si}$ cycling and Fe limitation in the southern ocean, Deep-Sea Research Part Ii-Topical Studies in Oceanography, 53, 601-619, 2006.

O’Neill, N. T., Dubovik, O., and Eck, T. F.: Modified Angstrom exponent for the characterization of submicrometer aerosols, Appl. Opt., 40, 2368-2375, 2001.

Schkolnik, G., Chand, D., Hoffer, A., Andreae, M. O., Erlick, C., Swietlicki, E., and Rudich, Y.: Constraining the density and complex refractive index of elemental and organic carbon in biomass burning aerosol using optical and chemical measurements, Atmos. Environ., 41, 1107-1118, 2007.

Schuster, G. L., Dubovik, O., Holben, B. N., and Clothiaux, E. E.: Inferring black carbon content and specific absorption from Aerosol Robotic Network (AERONET) aerosol retrievals, J. Geophys. Res., 110, D10S17, doi:10.1029/2004JD004548, 2005.

Schuster, G. L., Dubovik, O., and Holben, B. N.: Angstrom exponent and bimodal aerosol size distributions, J. Geophys. Res., 111, D07207, doi:10.1029/2005JD006328, 2006.

Seinfeld, J. H., Carmichael, G. R., Arimoto, R., Conant, W. C., Brechtel, F. J., Bates, T. S., Cahill, T. A., Clarke, A. D., Doherty, S. J., Flatau, P. J., Huebert, B. J., Kim, J., Markowicz, K. M., Quinn, P. K., Russell, L. M., Russell, P. B., Shimizu, A., Shi- 
nozuka, Y., Song, C. H., Tang, Y. H., Uno, I., Vogelmann, A. M., Weber, R. J., Woo, J. H., and Zhang, X. Y.: ACE-ASIA - Regional climatic and atmospheric chemical effects of Asian dust and pollution, Bulletin of the American Meteorological Society, 85, 367-380, 2004.

Shettle, E. P., and Fenn, R. W.: Models of aerosols of lower troposphere and the effect of humidity variations on their optical properties, Air Force Cambrige Lab., Hambscom, Air Force Base, Mass., 1979.

Simonson, R. W.: Airborne dust and its significance to soils, Geoderma, 65, 1-43, 1995.

Sinyuk, A., Dubovik, O., Holben, B., Eck, T. F., Breon, F. M., Martonchik, J., Kahn, R., Diner, D. J., Vermote, E. F., Roger, J. C., Lapyonok, T., and Slutsker, I.: Simultaneous retrieval of aerosol and surface properties from a combination of AERONET and satellite data, Remote Sensing of Environment, 107, 90-108, 2007.

Smirnov, A., Holben, B. N., Eck, T. F., Dubovik, O., and Slutsker, I.: Cloud-screening and quality control algorithms for the AERONET database, Remote Sensing of Environment, 73, 337349, 2000.

Sokolik, I. N. and Toon, O. B.: Incorporation of mineralogical composition into models of the radiative properties of mineral aerosol from UV to IR wavelengths, J. Geophys. Res., 104, 9423-9444, 1999.

Stern, E., Gradus, Y., Meir, A., Krakover, S., and Tsoar, H.: Atlas of the Negev, Keterpress Enterprises, Jerusalem, 1986.
Streets, D. G., Bond, T. C., Lee, T., and Jang, C.: On the future of carbonaceous aerosol emissions, J. Geophys. Res., 109, D24212, doi:10.1029/2004JD004902, 2004.

Sugimae, A.: Elemental constituents of atmospheric particulates and particle density, Nature, 307, 145-147, 1984.

Tsidulko, M., Krichak, S. O., Alpert, P., Kakaliagou, O., Kallos, G., and Papadopoulos, A.: Numerical study of a very intensive eastern Mediterranean dust storm, 13-16 March 1998, J. Geophys. Res., 107(D21), 4581, doi:10.1029/2001JD001168, 2002.

Watson, A. J., Bakker, D. C. E., Ridgwell, A. J., Boyd, P. W., and Law, C. S.: Effect of iron supply on southern ocean $\mathrm{CO}_{2}$ uptake and implications for glacial atmospheric $\mathrm{CO}_{2}$, Nature, 407, 730733, 2000.

Wiggert, J. D., Murtugudde, R. G., and Christian, J. R.: Annual ecosystem variability in the tropical Indian Ocean: Results of a coupled bio-physical ocean general circulation model, Deep-Sea Research Part Ii-Topical Studies in Oceanography, 53, 644-676, 2006.

Zhang, X. Y., Gong, S. L., Shen, Z. X., Mei, F. M., Xi, X. X., Liu, L. C., Zhou, Z. J., Wang, D., Wang, Y. Q., and Cheng, Y.: Characterization of soil dust aerosol in China and its transport and distribution during 2001 ACE-Asia: 1. Network observations, J. Geophys. Res., 108(D9), 4261 doi:10.1029/2002JD002632, 2003. 